\title{
Impoverishment Risks in DIDR in Dar es Salaam City: The Case of Airport Expansion Project
}

\author{
Dawah Lulu Magembe-Mushi \\ School of Spatial Planning and Social Sciences, Ardhi University, Dar es Salaam, Tanzania \\ Email: dimushi2000@yahoo.com
}

How to cite this paper: Magembe-Mushi, D. L. (2018). Impoverishment Risks in DIDR in Dar es Salaam City: The Case of Airport Expansion Project. Current Urban Studies, 6, 433-454.

https://doi.org/10.4236/cus.2018.64024

Received: June 28, 2018

Accepted: November 5, 2018

Published: November 8, 2018

Copyright $\odot 2018$ by author and Scientific Research Publishing Inc. This work is licensed under the Creative Commons Attribution International License (CC BY 4.0).

http://creativecommons.org/licenses/by/4.0/

\begin{abstract}
Contrary to the State's rhetoric of inclusive governance, urban poor is excluded from planning for infrastructure development and resettlement processes, leading to a lack of understanding of their needs by the state resulting to their subsequent impoverishment after resettlement. This paper discusses impoverishment risks experienced by massive population resettlements from airport expansion project in Dar es Salaam City, Tanzania. The risks experienced were outcomes of procedures followed and policies/acts adopted in the implementation process. Literature on impoverishment risks experienced during displacement shows that poorly managed displacement processes and lack of adherence to policies and guidelines exposed the affected population to impoverishment risks for both short and long terms. The actualization of the risks depends on the preparedness of the project implementers or the government's enforcement bodies in implementing the resettlement project. This paper draws empirical evidences obtained from studies conducted in 2014 and 2017. It discusses eleven impoverishment risks experienced by both the displaced and hosting communities at different periods and magnitudes. The paper argues that the displaced poor households have been further impoverished in the course of resettlement process as a result of limited attention to the risks of impoverishment both in policies and in local government practices. This paper realises that there is an urgent need for a resettlement policy which insists on participation of the affected communities that would eliminate impoverishment risks.
\end{abstract}

\section{Keywords}

Development-Induced Displacement and Resettlement (DIDR), Impoverishment Risk, Compensation, Dar es Salaam, Tanzania 


\section{Introduction}

Displacement can be defined as the process of dislocating people from their long-time and permanent residences through acquisition of land to be used for a different activity. Development related changes happened in developing countries in the $20^{\text {st }}$ century, to a greater extent than in the developed countries. These changes have caused land acquisitions which have led into involuntary displacement of large populations. In 2007-2008, 4.31 million people worldwide were affected by implementation or threatened forced evictions (COHRE, 2009 in Hooper \& Ortolano, 2012). In Africa from 1980 to 1986, about 33 percent of all the World Bank assisted development projects on transportation, water and urban development caused involuntary resettlement and the proportion grew to 57 percent between 1987 and 1995 (Robinson, 2003: p. 19). Tanzania, being one of the developing countries, also experiences mass involuntary displacements of population for a variety of reasons. Such projects include those of villagelization $^{1}$, site and services and squatter upgrading, road expansion and highway construction, airport and harbour construction and expansion (Magembe-Mushi \& Lupala, 2015; TAA, 2010), the development of new centres, capital city and satellite city development and so on. All these projects and others of this nature have caused involuntary displacement and resettlement and in the same way, these kinds of projects will continue to displace and resettle large numbers of people in the country. For example, the resettlement programme through villagization policy intended to facilitate a large number of rural communities to have access to basic services and facilities within their reach; so as to improve living conditions by providing communal social services and facilities. However, the programme came with its negative impacts, such as concentration of people and livestock in particular places which affected the economy and environmental conditions. It increased distances between settlements, farms and grazing lands. This shows that this kind of displacement process comes with both positive and negative impacts which need to be fixed so as to have more positive ones.

\subsection{Development Induced Displacement and Resettlement in Tanzania}

Stanley (2004) describes development-induced displacement and resettlement (DIDR) to be part and parcel of urban development, of which the focus is on physical development projects that require land expropriation. Stanley added that the DIDR is so far, the leading cause of vast displacement, although there is no precise data that exists on the number of people affected by DIDR. In Tanzania, these displacements are the result of urban development, transport and infrastructure programmes which usually take place in cities. This is due to the fact that within the cities, there is large population which goes together with scarcity of land. In that case, any new development introduced within the city results ${ }^{1}$ Villagization was a socialism policy which required people to live together in villages so that they can share all the basic facilities provided by the government. 
into change of land use which most of the time affects the existing population of the urban residents. This country so far has five cities, Dar es Salaam, Mbeya, Mwanza, Arusha, Tanga and recently Dodoma. Dar es Salaam, being the largest has the population of more than 4.4 million people, followed by Mwanza, (2.8 million), Mbeya (2.7 million), Tanga and Dodoma (2.0 million) and Arusha (1.7 million) (NBS \& OCGS, 2013) people. In Dar es Salaam city projects such as port/harbour expansion, highway extension, airport expansion, gas pipeline and the development of satellite cities resulted into displacement and resettlement of large population (see Figure 1).

This paper analyses the airport expansion project (project no 5 in Figure 1), which completely displaced two settlements, Kipawa and Kigilagila, and resettled the affected property owners more than 12 kilometres away from the project area (TAA, 2010). The Julius Nyerere International Airport (JNIA) expansion project is located within Kipawa Ward in Ilala Municipality (see Figure 2). The Ward comprises various land uses which included: residential, industrial,

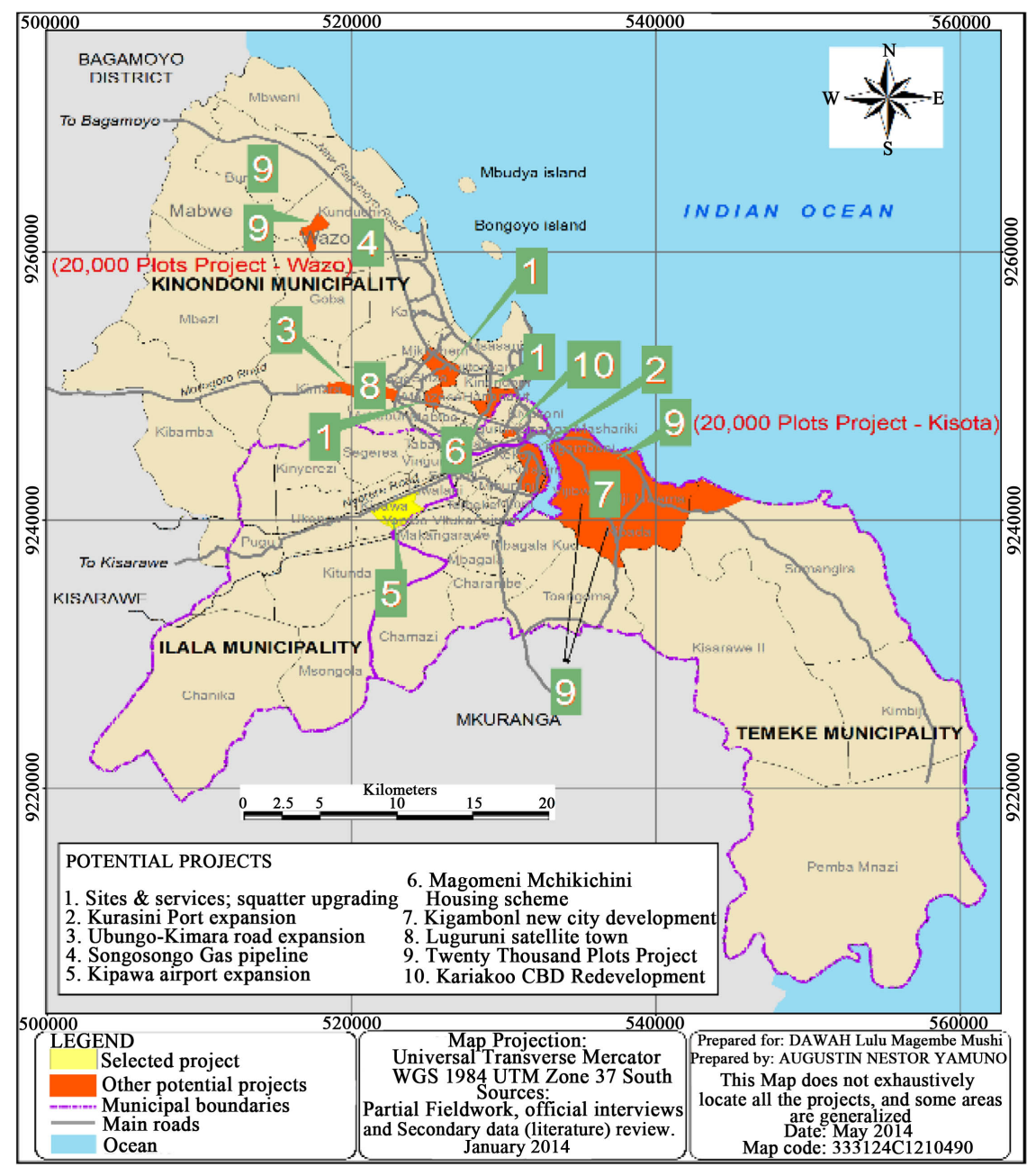

Figure 1. Some of development projects which have caused displacement of previous land users. Source: Magembe-Mushi, 2014: p. 86. 


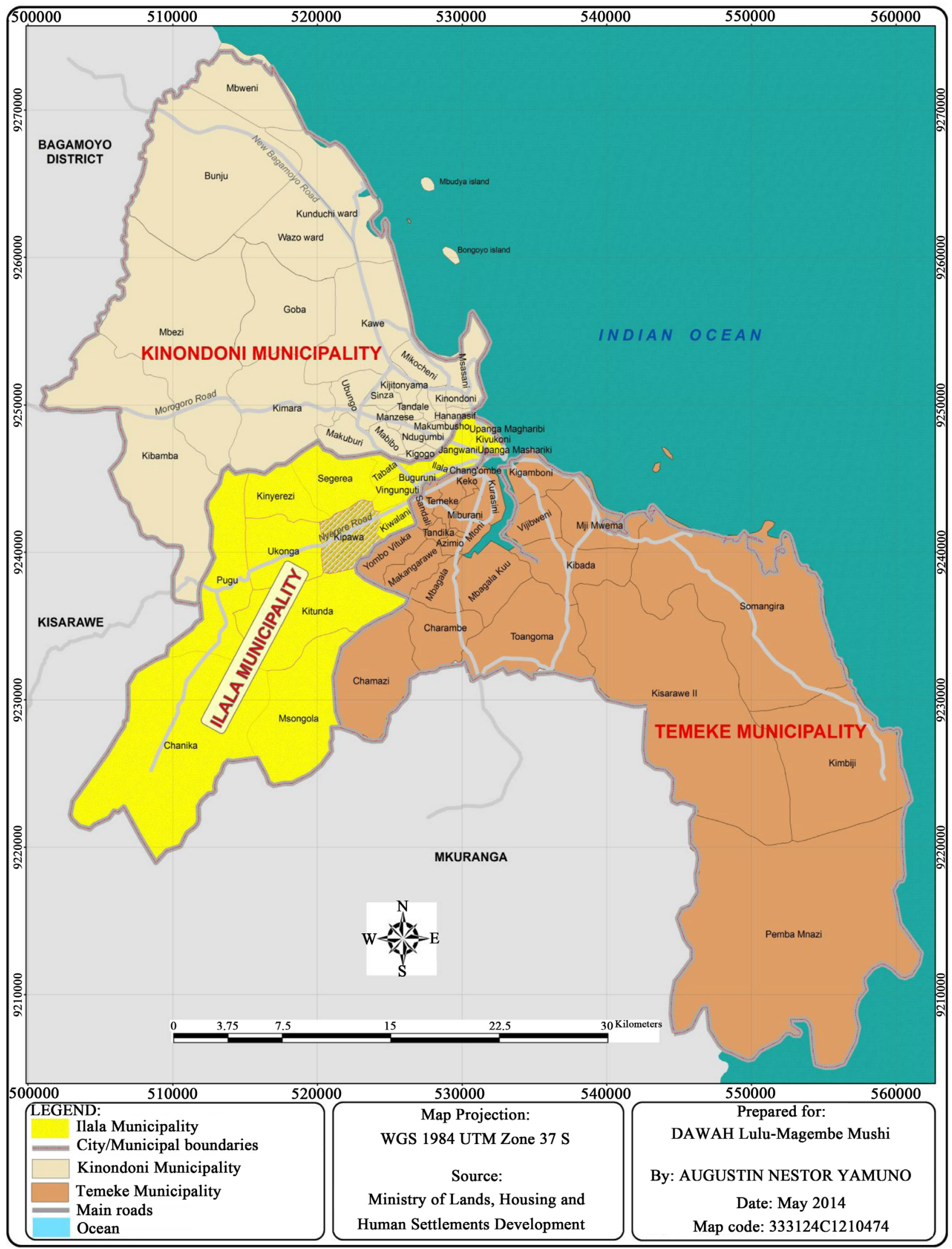

Figure 2. Location of Kipawa Ward in Dar es Salaam City. Source: Magembe-Mushi, 2014: p. 96. 
institutions and it is also accommodating the country's most active international airport, the JNIA. The affected areas were occupied by informal settlements, which proliferated in a land provided for future institutions expansion in the Dar es Salaam Master Plan of 1979. These settlements were occupied by more than 2000 house owners (Magembe-Mushi, 2014). According to the 2002 population census, the Ward had a population of 50,000 people. In 1997 came the idea of expanding the international airport so as to increase its capacity and services to meet international demands and standards. Within such a framework, 2084 Kipawa and Kigilagila suburban properties were earmarked for demolition and their land was compulsorily acquired to pave the way for the expansion of the airport (TAA, 2010). By doing so, the project caused total displacement of the two settlements. The airport expansion project aims at increasing the capacity of the airport to handle more flights from 1.5 to 5 million passenger arrivals annually over the next 10-year period. The Tanzania Airports Authority (TAA) reported that more than 15 percent annual growth in aeroplane traffic is expected after the expansion. Therefore, the expansion will contribute to the economic growth of the country (ibid). This paper explores the impoverishment risks which were faced by the displaced population in relation to the guiding policy and regulations which were applied in the process.

\subsection{Methodology}

This paper is based on a research conducted in 2014 and the other one in 2017. Being a case study research, empirical data were collected by using multiple data collection methods such as: in-depth interviews, household surveys, official and key informant interviews, non-participatory observations, photographic registration and mapping. These data collection methods were applied to the displaces in their new areas, hosting communities, previous and current local leaders within the resettlement areas; project implementers, and municipal authorities in the concerned municipality. Through these methods, processes, procedures and regulations applied in displacing and then relocating the affected people were documented and analysed through data analysis programmes, and other map making applications.

By using in-depth interviews personal stories were shared on how relocations have resulted into impoverishment risks which are the main concern of this paper. About 211 surveys, 37 in-depth interviews and 13 officials and key informant interviews were conducted to both displaces and hosting communities in the four resettlement areas within Ilala Municipality in Dar Es Salaam city. The research also reviews policies, project documents and other literature in order to answer the following three questions: 1) Are the poor further impoverished after resettlement? 2) Are there gaps in policy pertaining to impoverishment risks? And 3) Was there effective community participation in critical decisions related to displacement and resettlement in the airport expansion project? 


\section{Urban Development Policies Applied in Tanzania}

The DIDR often affects the economically, politically and socially weak and marginalized groups in a population. At individual and community levels, the impoverishment risks associated with resettlement can be felt more intensively by certain segments of the displaced population. In Tanzania, and most developing countries, project sponsors, such as government institutions, development agencies, credit agencies and private developers, had no clear policy or guidelines on how to conduct involuntary resettlement. It is common for the State to have policies guiding different domains, many of which deal solely with the legal process of expropriation, a number of which outline compensation mechanisms, but none of which deal in detail with resettlement (Stanley, 2004). This section provides different provisions which were applied by some of the projects on resettlement in the absence of one clear resettlement policy in Tanzania.

\subsection{World Bank Resettlement Policy Framework}

The World Bank was the $1^{\text {st }}$ institution in the 1980 s to come up with policy on involuntary resettlement caused by any development agency engaged in funding or implementing development projects that caused displacement. The Bank made sure that the displacement and resettlement of people became an essential and not a side-line part of project planning and implementation. In creating such an importance, the World Bank formulated Operational Policy (OP) on Involuntary Resettlement. The OP Section 4.12 was first drafted in 1980 and is updated periodically. It has the following objectives which were applied in some of the resettlement projects in Tanzania:

- Where involuntary resettlement and land acquisition is unavoidable, resettlement and compensation activities should be conceived executed and provided with sufficient investment resources to the displaces as an opportunity to share project benefits.

- Displaced and compensated persons will be meaningfully consulted and will have opportunities to participate in planning and implementing resettlement and compensation programs.

- Displaced and compensated persons will be assisted in their efforts to improve their livelihoods and standards of living or restore them, in real terms, to pre-displacement levels or higher (The World Bank, 2001: p. 1).

\subsection{African Development Bank's (AfDB) Involuntary Resettlement Policy}

Just like the World Bank's, this Involuntary Resettlement Policy (IRP) was developed to cover the involuntary displacement and resettlement of people caused by this bank financed projects. The IRP applies to projects which cause relocation or loss of shelter, loss of assets or have impacts on the existing livelihoods. The policy has an overall goal of poverty reduction therefore, assists the bank and its borrowers to address resettlement issues in order to mitigate the negative 
impacts of the implemented projects i.e. displacement and resettlement which can provoke changes that could dismantle settlement patterns and modes of production, disrupt social networks, cause environmental damages and diminish people's sense of control over their lives (AfDB, 2003). The Bank intends to establish a sustainable economy to such affected society.

The overall goal of this policy is to ensure that the displaced people are treated equitably and that they share the benefits of the project that has caused their relocation. Other objectives include; to ensure that displaced people receive resettlement assistance, preferably under the project so that their standards of living, earning capacity and production levels are improved (ibid).

The policy advises that relocation criteria should consider involving the affected families, both the relocated and their hosts in discussions and selection of sites and, the resettlement plan should consider the legal and institutional framework of the country in question (AfDB, 2003: p. 19).

\subsection{National Land Policy of 1995}

The National Land Policy of 1995 (in review), guides all issues relating to land use in Tanzania. Among the issues that are stipulated in the policy include recognition of land ownership, and resources in and on it. It addresses issues of land tenure, citizens' rights of access to land, and land delivery system. It also advocates fair and prompt compensation when land rights are interfered by the government. All these issues are very crucial when it comes to land acquisition which results into displacement and resettlement. The Policy has fundamental principles which have been used in guiding land acquisition for urban development projects. In Section 4.1.1 Sub-section (i) a, b, c, and d state:

- All land in Tanzania is public and vested in the President as a trustee on behalf of all citizens, no one owns land in Tanzania but rather use it for a certain period of time.

- The policy acknowledges that land itself has value.

- The government insists on paying full, fair and prompt compensation when land is compulsorily acquired.

- The government observes justice by making it possible for the acquisition of land in the public interest to be challenged in court, as it states in Section 4.2.16 (iii).

- Compensation for land acquired for public interest shall be on the basis of opportunity cost, market value, disturbance allowance, transport allowance, loss of profit or accommodation; and the original cost of acquiring or getting the land as provided in Section 4.2.20 (i-vii) (URT, 1997).

These principles go with that which has been stipulated by the financing institutions above, though there are differences in considering compensation and the planning approach. This policy is accompanied with other Acts such; Land Acquisition Act No 47 of 1967, Land Act No. 4 of 1999, Urban Planning Act of 2007. 


\section{The Correlation between Impoverishment Risks and Policy Framework in DIDR in Dar Es Salaam}

This section discusses common risks as described by Cernea (1996a), Cernea and McDowell (2000), Downing (2002), Robinson (2003), Magembe-Mushi (2011), and others. These risks include: landlessness, joblessness, homelessness, marginalization, increased morbidity, food insecurity, and loss of access to common assets and services, social disarticulation, family disintegration, violation of human rights and disruption of formal education. The following sub sections define the risks, and describe how they were felt within the case project in Dar es Salaam. It also compares the provisions from the guiding regulations as discussed in section 2 to see how they were/not applied in the displacement and resettlement processes and the degree at which the risks were felt by the affected people.

\subsection{Landlessness}

Landlessness was explained by Cernea as the first risk to happen when displacement and resettlement occurs once land is expropriated. Landlessness removes the main foundation upon which people's productive systems, commercial activities and livelihoods are constructed. According to Cernea (1996b: p. 18), this is a principal form of de-capitalization and pauperization of displaced people as they lose both natural and man-made capital. For the urban poor, such as those in Dar es Salaam city, land not only provides a place to live, but also acts as the main resource supporting different livelihood strategies. The urban poor use land as a place for their homes, to generate economic activities and to create social networks which they can depend on (Magembe-Mushi, 2011: p. 32).

\section{Policy provisions:}

In policies and frameworks discussed above, the major concern when it comes to land acquisition was the compensation which has to consider the land value in relation to location of the acquired land. Also, the location of the resettlement areas has to be beneficial to the relocated population. For example, the ADB advocates for relocation sites to have services as much as the acquired land.

\section{Reality:}

The project applied the Land Policy, Land Act of 1999 and Land Acquisition Act of 1967, but the reality was contrary to the provisions. The affected residents from the Kipawa and Kigilagila settlements were displaced and relocated up to $22 \mathrm{kms}$ away from their previous settlements (see Figure 3: Resettlement areas). They were taken much further from the city centre, and away from their income generating activities since the new settlements were at the peri urban areas and less developed, compared to where they were before. More interesting for the airport expansion project is the fact that it made the hosting communities to be landless. That happened when farmlands were acquired and subdivided into plots and allocated to more than 3000 households of the displaced people and the farm owners as well as. That leaves the farm owners farmland-less as they were left with a plot or two, with their houses on it, the rest was allocated to new 


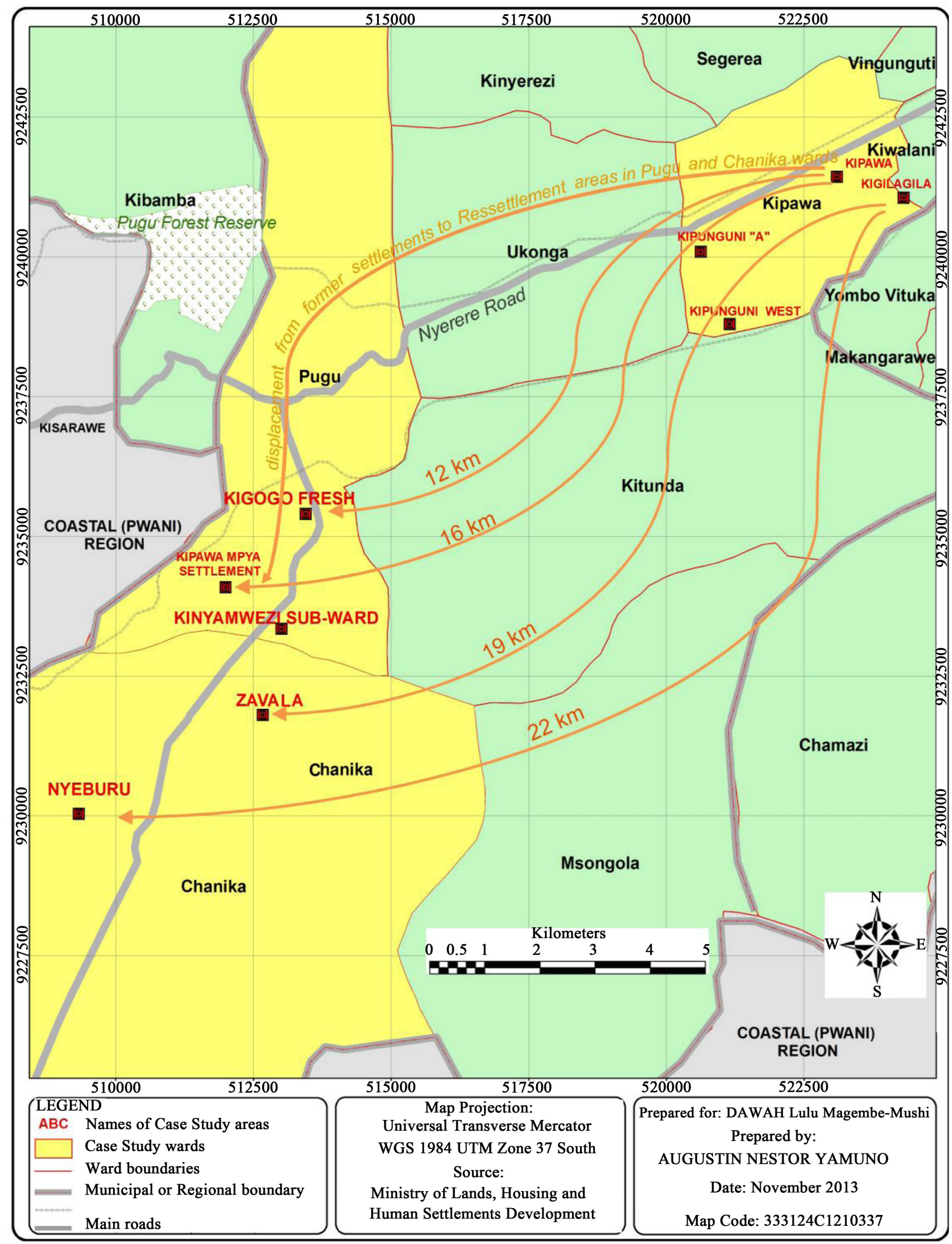

Figure 3. Kipawa ward and the resettlement areas in Pugu and Chanika Wards. Source: Magembe-Mushi, 2014. 
comers. In that case these host communities lost their farmlands, grazing areas and become landless as well as jobless as they had to change their livelihood activities.

\subsection{Joblessness}

As defined by Cernea (1996b), joblessness is the state of having lost employment or any other income generating activity. Such a situation can affect those who are in particular employment sectors and those who are self-employed. Joblessness can continue long after physical displacement and resettlement has occurred. Cernea added that creating new jobs is difficult and requires substantial investment, unless a fair and rightful allocation of resources is practised for both the displaced residents and hosting communities (Cernea, 1996b: p. 19). Considering Cernea's point, substantial investments and the judicious allocation of resources can create new jobs for the displaced and the host residents.

\section{Policy provisions}

The World Bank and ADB have provisions for livelihood restoration strategies that ensure resettlement plans offer support after displacement; for a transitional period, and other long term measures such as land preparation, job opportunities and credit facilities. The local policies and Acts speak about compensation that will consider opportunity costs and loss of profits.

\section{Reality}

Even if the local policies and Acts had provisions on that, the affected population for the airport expansion project did not receive any assistance when it comes to livelihood restorations. Being sent far away from their settlements in which they lived for more than 10 years, they lost all their income generating opportunities which were not compensated for. Their previous settlements were closer to the city, accessed by large population, and with full of opportunities, and services. Some of the residents had their income generating activities at their own door steps. That was not possible in the resettlement areas which were newly surveyed with low population density and scattered settlements. From the research conducted in 2017 the population has increased from 4320 of 2014 to 5111 households. This indicates that the increase of population will trigger job creation within the settlements.

\subsection{Homelessness}

For Downing (2002: p. 10) homelessness is the loss of house-plots, dwellings and shelter. Such a loss can be temporary for many of the displaced people, but for some, homelessness or the worsening of their housing standards can be a lingering condition (Cernea, 1996a: p. 20). It goes further into loosing social services and facilities, inconveniences and disturbances while resettling, as well as loosing culture, space and identity, costs of reconstructing new dwellings, being far from your work place etc. (Cernea \& McDowell, 2000).

\section{Policy provisions}


All the policies and Acts have provisions for compensating on loss of properties due to land acquisition. Some of the provisions go further and consider transport and disturbance allowances. E.g. the Land Act of 1999 considers compensation to include: "the market value of the real property, transport and disturbance allowances, loss of profit or accommodation, ..." (URT, 1999).

\section{Reality}

When it comes to implementing the provisions in the airport expansion project, it was found that the compensations were not provided as stipulated. There were disagreements in the valuation process whereby property owners had a feeling that their properties were under-valued, and compensated in lumpsum not knowing what amount was for what item as the Act provides. Even though the affected property owners were compensated, they still became temporarily homeless, some for a couple of weeks and some for months (see Plate 1). On the other hand, some of the hosting community members (about 4 farm owners) were displaced and their houses demolished as there were found to be in the areas allocated for social facilities within the resettlement areas.

\subsection{Marginalization}

Downing (2002) defines marginalization to be a loss of self-esteem as a result of being considered a newcomer or outsider within a society. Robinson added that marginalization occurs when families lose economic power and spiral on a downward mobility path. This happens because many individuals cannot use their previously-acquired skills at the new location. In such cases, human capital is lost or rendered inactive or obsolete (Robinson, 2003: p. 12). Patel et al. (2015) added that marginalization can be through hostility from the host community as well as loss of understanding in the community.

\section{Policy provisions}

In both local and financial institutions' policies reviewed above, none of them had provisions for emotions or trauma caused by the processes. The guiding regulations were only concerned with physical losses but not emotional or psychological trauma such as marginalization.
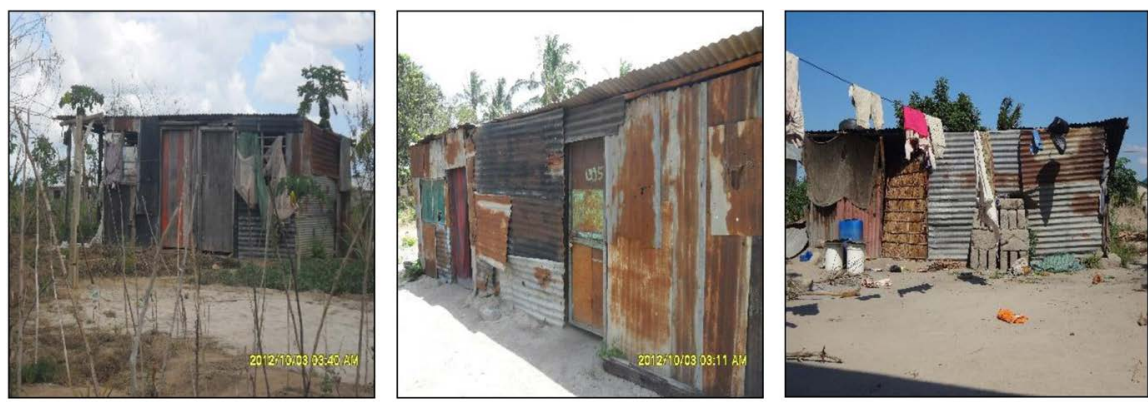

Plate 1. Some of the temporary huts used as shelter during the resettlement process, made of materials from demolished houses from previous settlements. Source: Magembe-Mushi, 2014. 


\section{Reality}

Having no provisions whatsoever in the guiding regulations marginalization were so much felt by the new comers from the airport expansion project. For these people, they mostly suffer hostility from their hosts. That was contributed by the fact that the host communities were not yet compensated for the loss of their farms acquired for plots subdivisions for resettlements. Having lost their property, the host communities resisted to let the new comers occupy their land. The hostility was through vandalising housing constructions of the displaced people, chasing them away, not letting them use facilities like wells dug by the hosting community. The marginalization lasted for a number of months but somehow affected both the hosting community and the new comers within the resettlement areas.

\subsection{Increased Morbidity}

Cernea and McDowell (2000: p. 23) again state that massive population displacement threatens to cause serious declines in health levels. Displacement-induced social stress and psychological trauma are sometimes accompanied by the outbreak of relocation-related illnesses, particularly parasitic and vector-borne diseases, such as malaria and schistosomiasis. Unsafe water supply and improvised sewage systems increase vulnerability to epidemics, chronic diarrhoea, dysentery and so on. The weakest segments of the demographic spectrum-infants, children, and the elderly are affected most strongly (ibid). Of all the risks of displacement, increased morbidity was specifically said to happen when there is mass population displacement as large scale of displacement was associated with a decline in health levels.

\section{Policy provisions}

The ADB advocates for relocation sites to have services as much as the acquired land that means availability of social services and facilities in the resettlement areas have to be taken care of. Also, the compensations provided were meant to put the affected persons to the level they were before displacement if not making it even better. This should be the same even in the availability of social services.

\section{Reality}

In the airport expansion project, increased morbidity was very much felt by the displaced community. That was because the displaced lost all the social facilities that they used to enjoy while in their previous settlements. These people did not have access to clean and safe water, they had to dig shallow wells so as to get water (see Plate 2). This led into eruption of water-borne diseases such as Typhoid, Cholera, and dysentery. Up to 2017 the settlement has not yet had clean and safe water supply; $63 \%$ depend on rainwater harvest, $17 \%$ get water from swamps and $20 \%$ from shallow wells. People are still suffering from diseases such as typhoid, bilharzia and diarrhoea and the rate increases during rainy seasons. 

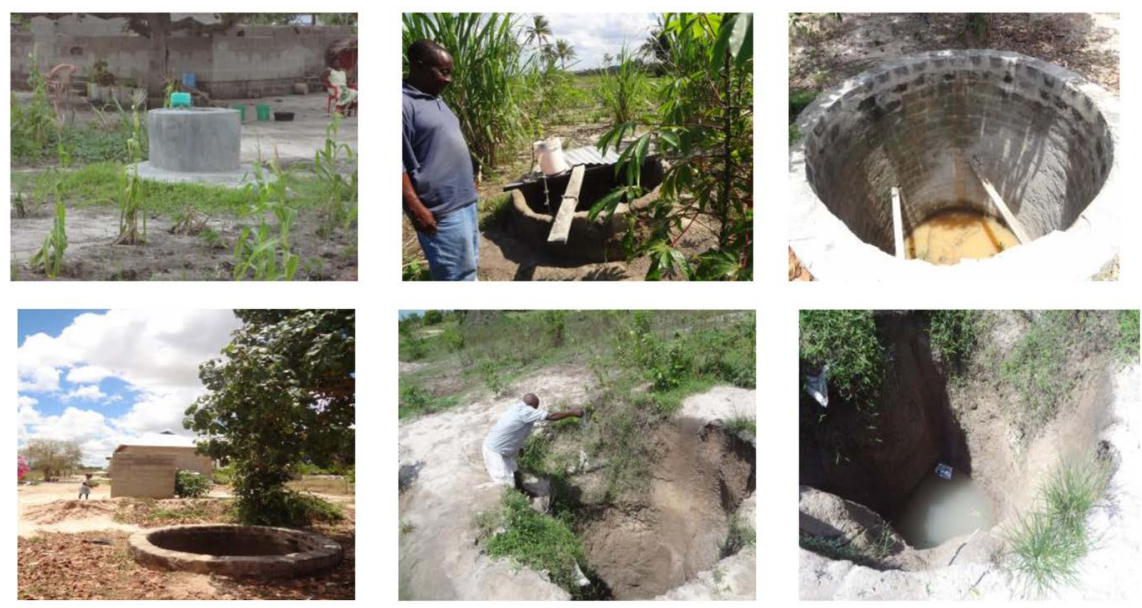

Plate 2. Sources of water found in the resettlement areas. Source: Magembe-Mushi, 2014.

\subsection{Food Insecurity}

According to Cernea and McDowell (2000: p. 23) food insecurity and undernourishment are both symptoms and results of inadequate resettlement. Forced uprooting increases the risk that people will fall into a state of temporary or chronic undernourishment. During physical relocation, sudden drops in food crop availability and incomes are predicted. Subsequently, as rebuilding regular food production capacity at the relocation site may take years, hunger or undernourishment tends to become a lingering long-term effect (FAO, 2008). Also, decreased access to fair price shops i.e. public distribution shops with subsidized goods to poor (Patel et al., 2015), was considered to be the cause of food insecurity for the displaced people.

\section{Policy provisions}

Again, food insecurity was not explicitly considered in the policy provisions. The compensations given for the loss of property was considered to take care of the loss of harvests in case a farmland or crops affected due to land acquisition.

\section{Reality}

In the case of the airport expansion project the displaced and the host communities both suffered from food insecurity due to resettlement process. For the case of the new comers they missed shopping facilities like nearby shops and market places, even transport facilities which could have taken them to where the missing facilities were available. In that case, some of them had to go for one meal a day due to scarcity of food and lack of income which was contributed by being jobless. For the case of host community, being farmers who lost their farms they also lost their income as well as food supply for their families. Losing their farmland made them lose both income as well as food.

\subsection{Loss of Access to Common Facilities}

Common resources are services or facilities which are commonly provided by the government to be commonly utilized or accessed by the public. Such re- 
sources can include, but are not limited to, access roads, community halls, shopping facilities, health centres, burial grounds, and play grounds. Moving away from such facilities can create disturbances or changes in the life style of the urban poor and result in unfair and injudicious allocation of resources (Cernea, 1996a and Magembe-Mushi, 2011: p. 36). Decreased access to education and health services, school dropout ratio and loss of school attendance days, increased distance, travel cost and monthly cost for education vis-à-vis income of the parents, decreased access to hospitals in emergencies (Patel et al., 2015), all these are caused by loss of access to social services.

\section{Policy provisions}

This factor is also not considered in policies that were reviewed. That is because the policies assume that resettlement action plan could have made sure that the resettlement areas qualify for human habitation, that is provided with all the necessary facilities. In that case, the loss of access to common facilities or resources is not considered eligible for compensation.

\section{Reality}

Until 2017, the resettlement areas were lacking almost all the social facilities. The hosting communities together with new comers depended on the neighbouring settlements for services and facilities (see Figure 4). As a result, there were congestion in primary schools due to increase of school going children who relocated with their parents. Also, the increase of population and provisions of new neighbourhood in the areas which were previously farmland changed lifestyle of the hosting community. That is, they were characterized as urban dwellers while they lack all the facilities and services required for the urban kind of life. The settlements have not yet received electricity supply. They depend on solar and other sources of energy such as kerosene and charcoal for lighting and cooking respectively.

\subsection{Social Disarticulation}

As was explained by Cernea (1996a), social disarticulation is a process which disperses and fragments communities, patterns of social organization and interpersonal ties. It is a loss of valuable social capital. Robinson (2003) adds that, it is the situation where society is disarticulated; "when people are forcibly moved, production systems are dismantled, long-established residential communities and settlements are disorganized, while kinship groups and family systems are often scattered. Life sustaining social networks that provide mutual help are rendered non-functional. The trade links between producers and their customer base are interrupted, and the local labour market is disrupted. Formal and informal associations, and self-organized services, are wiped out by sudden scattering of their membership" (Robinson, 2003: p. 12). From Robinson's argument, social disarticulation is more than just a dismantled society; it can also lead into other risks such as joblessness and family disintegration, political unrest as well as increased poverty. 


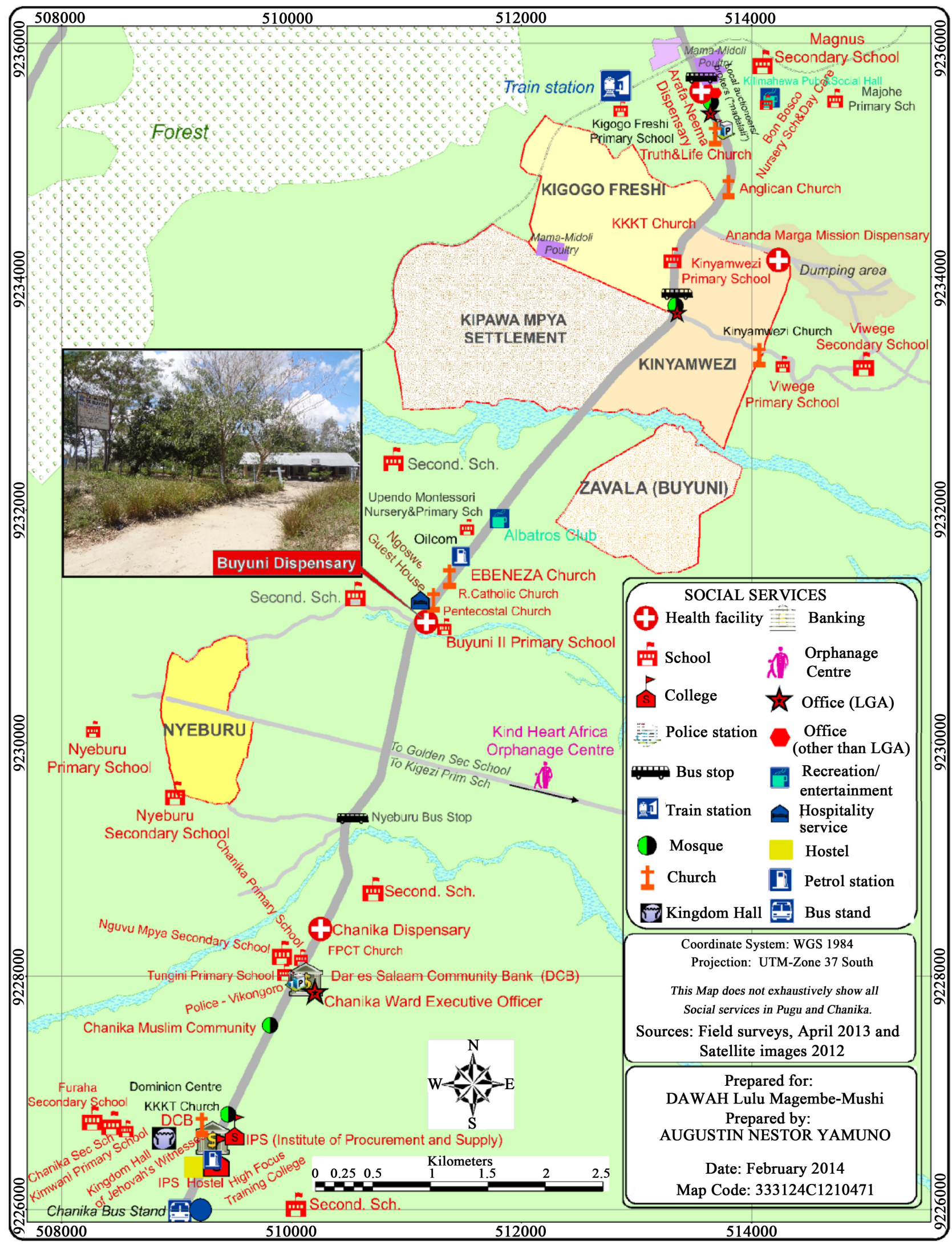

Figure 4. The available services and facilities in resettlement areas. Source: Magembe-Mushi, 2014. 


\section{Policy provisions}

Just like other non-physical losses, social/family disintegration was not considered in any policy provisions. The policies and other regulations assume that if the displacement and resettlement processes are planned and guided by regulations there shouldn't be such risks.

\section{Reality}

In real life situation, social disintegration was felt in the airport expansion project. The affected communities were disorganized and restored in four areas of Kigogo Freshi, Kipawa Mpya, Kinyawezi and Nyeburu (see Figure 4). These people had their production systems dismantled, and their residential communities disorganized. That was due to the fact that though they were taken to four different resettlement areas, plot allocation did not consider neighbours or even the arrangement that existed in their previous settlements. In that case, neighbours ended up living in different areas far from each other, ranging from 1 to $5 \mathrm{kms}$ away. That dismantled the existing ties and disorganized the communities. The long-lasting situation that the displaced community suffered from social disarticulation was the loss of trade links between producers and their customer and disruption of labour market. Also, employment opportunities for unskilled and cheap labour on daily basis weren't there due to low level of development as well as low population density.

\subsection{Family Disintegration}

This is also one of the challenges of displacement as it was explained by Cernea (1996a). It happens when family members have to live apart, due to lack of a common space to live in, which they had shared before the displacement (Downing, 2002). In urban development projects, which had a planned displacement and organized resettlement process, it is less likely that family disintegration will occur.

\section{Policy provisions}

Just like other non-physical losses, family disintegration was not considered in any policy provisions. The policies and other regulations assumes that if the displacement and resettlement processes are planned and guided by regulations there shouldn't be such risks.

\section{Reality}

Family disintegration was not experienced in the airport expansion project. Though for a period of time, ( 2 weeks to 3 months) the family members somehow had to sleep outside or share a single room as they relocated to the new settlements before finishing their new houses. That made families to build small temporary shelters (see Plate 1) while waiting for their main houses to finish.

\subsection{Violation of Human Rights}

Forced evictions and involuntary resettlement of individuals, families and com- 
munities rank among the most widespread human rights violations in the world (Hooper \& Ortolano, 2012: p. 1). Robinson (2003: p. 13) adds that violation of human rights as one of the risks of displacement and resettlement processes. $\mathrm{He}$ states that displacement from one habitual residence and the loss of property without fair compensation can, in itself, constitute a violation of human rights.

Robinson added that the violation will also be of civil and political rights, including the loss of one's political voice when displaced and resettled.

\section{Policy provisions}

When it comes to participation in decision making the affected people, all the policies and Acts reviewed advocated for it. The local Acts went further giving the affected people rights to refuse acquisition or take to court whatever they thought was not right during the processes of land acquisition and displacement.

\section{Reality}

It was found out that the affected community in the airport expansion project knew their rights and what they were entitled to during acquisition and resettlement. But still there were violation of those rights during the implementation of the project. There were about 343 among 1220 (Magembe-Mushi, 2014: p. 220) of property owners who refused to take compensation cheques because they did not agree with the amount given. There was an inhuman act when the displaced people were given only 3 months after receiving their compensation cheques to relocate to their new settlements. The affected communities complained that 3 months was such a short time for relocating a family which stayed for more than 10 years in that particular settlement. Such a short notice made the displaced community to become homeless temporarily. The other inhuman act is the fact that the affected population had to wait for more than 11 years for the implementation of the project (see Figure 5). That was because the process took too long and sometimes it was called off and called back in. That disturbed the affected people and made them live uncertain kind of life, thinking each day was their last in the settlement.

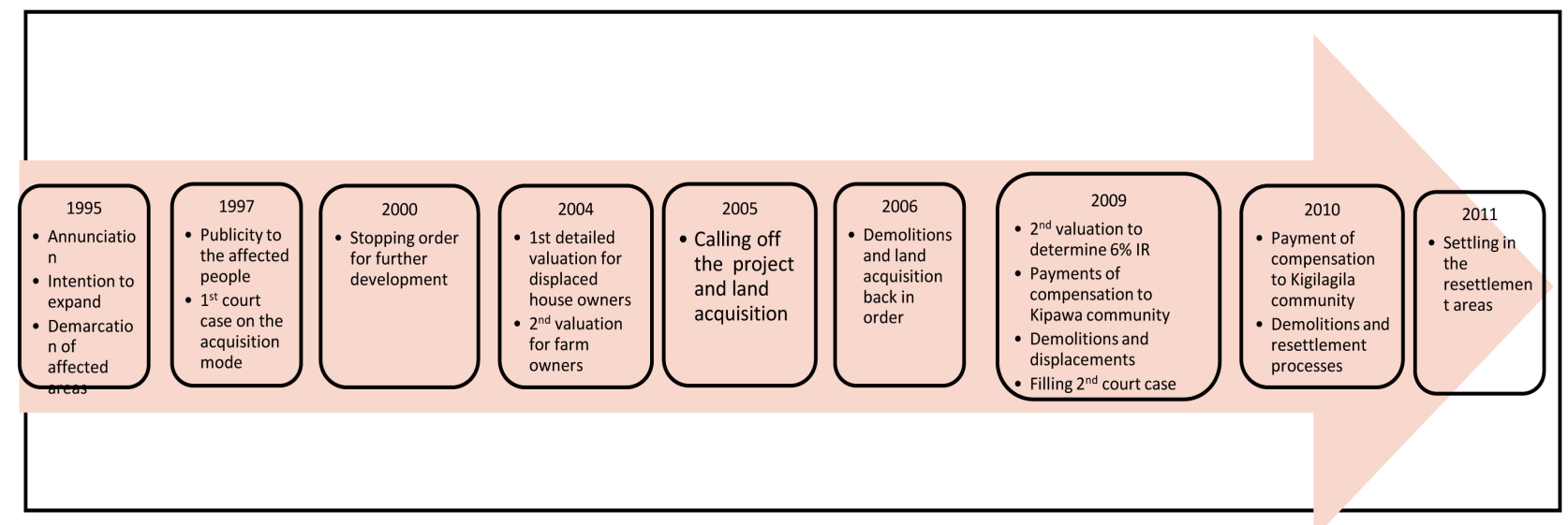

Figure 5. The Displacement process. Source: Magembe-Mushi, 2014. 


\section{Discussions}

Findings have shown that airport expansion project was among the rich cases for studying impoverishment risks caused by resettlement. That is, all the eleven risks were to different levels experienced by both the hosting and affected communities. It was unexpected for the hosting communities to suffer the same impoverishment risks in other cases, more intensively than the displaced community. Interesting enough, even the hosting community was subjected to displacement, when four households were completely demolished. That happened when their houses fell under the area which was allocated for social facilities in the newly planned neighbourhood. It was observed that in some interviewed households, the host community intensively suffered from the risks than the displaced ones. That was because these households lost their farms and their houses for the sake of the new comers. For example, the risks on food insecurity, landlessness and joblessness were much felt by the host community than the displaced ones (see Figure 6). Since these hosts were mainly depending on their farms for income generating and also food. Those farms were acquired and subdivided into plots for resettlement purposes.

The other fascinating factor that was observed in the airport expansion project is that of prolonged project implementation. It took 16 years (see Figure 5) from announcing the project to the actual resettlement. In between, there were other political events like the general election which called off the project in order to win the people's votes and call it back in after the elections. The delays and false statements made the affected people become so "uncertain" of their future. For eleven years, the displaced communities were in a stop order for further development or even renovation of their houses as they were waiting for demolition and relocation. As it was discussed by Patel et al. (2015), uncertainty became a major factor for the affected community to become poorer as they were living each day, for 11 years thinking that it was their last.

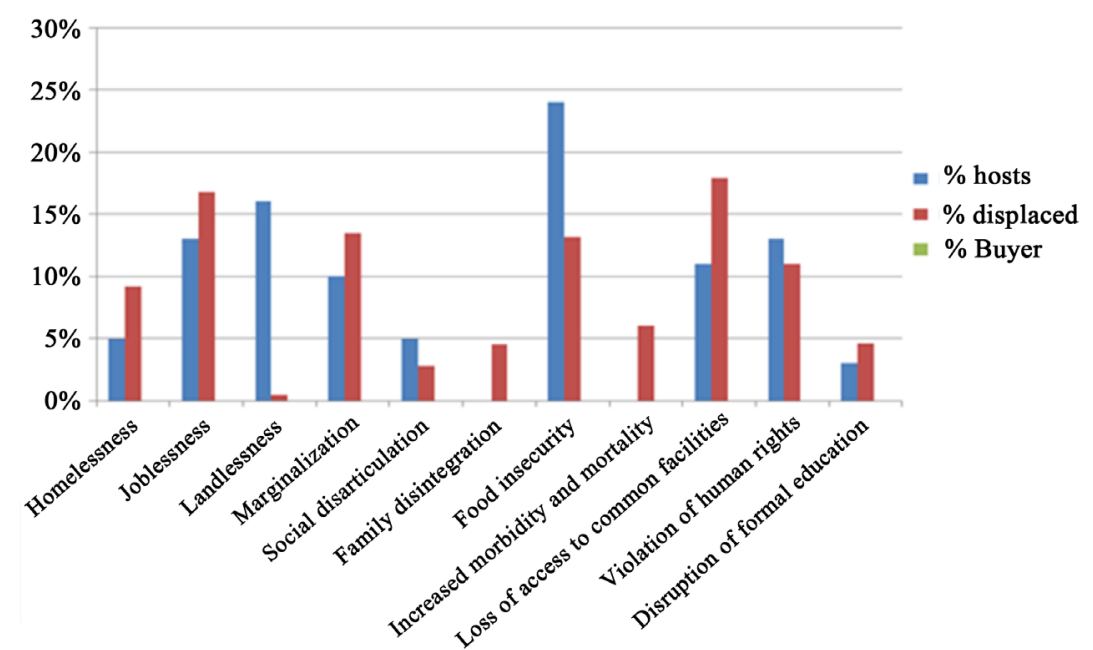

Figure 6. Impoverisment risks experienced in the Resettlement areas. Source: Magembe-Mushi, 2014. 
Also, poor participation of the affected communities in both processes (displacement and resettlement) was observed, regardless of the fact that it was so much emphasized by the guiding regulations. Absence or poor participation of the hosting communities made them more vulnerable to risks. That is because the resettlement plan did not consider their livelihoods nor their houses. The resettlement neighbourhoods were developed without their opinion nor their presence. That led to some of the houses to fall into the areas for social facilities and therefore demolished. That could not have happened in an area which was mostly farmland. If the communities had participated in the process of allocation of social facilities, demolition of the existing houses could have been avoided. Also, the hosting communities could have been made aware of the project and negotiate on the compensation terms that could have saved violence and marginalization which faced the displaced communities while resettling.

The issue of distance from the displaced settlement was also found to be one of the factors which caused all the impoverishment risks to be felt (Magembe-Mushi \& Lupala, 2015). The resettlement areas were from $10 \mathrm{kms}$ to 22 kms (Magembe-Mushi, 2014) away from their previous settlements. That is a long distance for a person to be able to continue with their normal life let alone benefiting from implemented project.

Figure 6 shows eleven impoverishment risks experienced by both displaced and hosting communities. With exception of two risks, increased morbidity and family integration, all other risks were faced by both displaced and hosting communities. Food insecurity was the most felt risk to the hosting communities as they lost their farms which were used for food supplies and income generation. That made landlessness to be second felt risks to the hosting communities. For the case of the displaced community, loss of common facilities was most felt followed by joblessness as they were resettled in newly developed neighbourhoods. The displaced community hardly felt the risk of landlessness as they were provided with big and surveyed plots while the hosting community lost many acres of their farms and some lost even their houses. All these were caused by not following the policy provisions which were used to guide displacement and resettlement processes in the absence of the country's resettlement policy.

\section{Conclusion}

Projects that lead to displacement and resettlement do exist and will continue to exist in developing countries, such as Tanzania with rapid urbanization and high level of poverty. In that case, these kinds of projects should not add on to the already existing poverty, but to find better ways of using the projects in reducing poverty and make the country develop. To fulfil that, implementation of resettlement projects should focus on improving the levels of affected land/property owners as much as they improve level of development by implementing such projects. Having policies and regulatory frameworks in place for such processes indicate a good intention of the concerned financier and the government to 
achieve their objective.

As it was discussed in the reviewed policies and acts above, there are great efforts in making sure that outcomes of the implemented development-induced projects are fair for both the implementers and the displacees of the project implementation through land acquisitions (URT, 2005). These guiding regulations were made in order to fulfil different purposes and they were in different documents. That made it inaccessible by the project implementers. That is why in some cases there were back and forth movements in land acquisition process. In other cases, the language used in some of the regulatory frameworks, provides loopholes to the implementers at the expense of the affected communities. For example, "fair and prompt" compensation was unclear to both the project implementers and to those who received the compensation. That created a room for diverse interpretations, hence unjustness and confusions among the affected communities.

Coming back to the three questions asked before:

1) Are the poor further impoverished after resettlement? The answer is yes, for a period of time. The first three months to one year in the resettlement areas, the displaced community became poorer than they used to be. The situation can be different afterwards as the community finds other alternatives which were available within their surroundings. That could have been the same to the hosting community, losing their farms and to some, their houses made them poorer for a certain period of time. It is assumed that they later on found other alternatives.

2) Are there gaps in policies pertaining to impoverishment risks? As illustrated in Figure 5, all the 11 effects of displacement and resettlement were somehow faced by both groups. These risks were contributed by lack of guiding regulations and to some extent, by not adhering to the provisions provided in the other frameworks. It can be recalled that these regulations were formulated so as to avoid negative effects which come in displacing and resettling affected population. So, it can be concluded that the gaps which existed in the guiding policies contributed to the risks that were faced by both groups of affected populations. On the other hand, having different provisions from different legislations e.g. land policy, land acts and ordinances, as reviewed in Section 2, contributed to failure to implement them in reality as well as prolonging the implementation of the resettlement process. In that case, it is urged that the country should prepare a resettlement policy which will consider all the provisions from different regulating bodies and legislations so as to avoid negligence and ambiguities while implementing a resettlement project. This will reduce the impoverishment risks which are associated with the process.

3) Was there effective community participation in critical decisions related to displacement and resettlement in the airport expansion project? It can be concluded that, there was no community participation in all the critical decisions related to displacement and resettlement for the airport expansion project. That 
is why it caused displacement by the displacees when the farm owners were also displaced. That could have been avoided if the community had participated in decision making process.

\section{Conflicts of Interest}

The author declares no conflicts of interest regarding the publication of this paper.

\section{References}

Africa Development Bank, AfDB (2003). Involuntary Resettlement Policy. PSDU. http://www.afdb.org/fileadmin/uploads/afdb/Documents/Policy-Documents/10000009 -EN-BANK-GROUP-INVOLUNTARY-RESETTLEMENT-POLICY.PDF

Cernea, M. M. (1996a). Bridging the Research Divide: Studying Development Oustees. In T. Allen (Ed.), In Search of Cool Ground: War, Flight and Homecoming in Northeast Africa. London: United Nations Research Institute for Social Development, Africa World Press and James Currey.

Cernea, M. M. (1996b). Understanding and Preventing Impoverishment from Displacement: Reflections on the State of Knowledge. In C. McDowell (Ed.), Understanding Impoverishment: The Consequences of Development Induced Displacement. Providence, RI: Berghahn Books.

Cernea, M. M., \& McDowell, C. (Eds.) (2000). Risks and Reconstruction: Experiences of Resettlers and Refugees'. Washington DC: World Bank.

https://doi.org/10.1596/0-8213-4444-7

Downing, T. E. (2002). Avoiding New Poverty: Mining-Induced Displacement and Resettlement. MMSD No 58. IIED and WBCSD.

FAO (2008). Compulsory Acquisition of Land and Compensation, Land Tenure Studies 10. Rome: Food and Agriculture Organization of United Nations (FAO).

Hooper, M., \& Ortolano, L. (2012). Confronting Urban Displacement: Social Movement Participation and Post-Eviction Resettlement Success in Dar es Salaam, Tanzania. Journal of Planning Education and Research, 32, 3.

http://jpe.sagepub.com/content/early/2012/04/03/0739456X12439066

Magembe-Mushi, D. L. (2011). Resettling Displaced Residents from Regularised Settlements in Dar es Salaam City, Tanzania: The Case of Community Infrastructure Upgrading Program (CIUP). Published Licentiate Thesis in Infrastructure, Planning and Plan Implementation. Stockholm: Royal Institute of Technology.

Magembe-Mushi, D. L. (2014). Mass Population Resettlement of Displaced Communities: A Case of Airport Expansion Project in Dar Es Salaam City. PhD Thesis, Ardhi University. (Unpublished)

Magembe-Mushi, D. L., \& Lupala, J. M. (2015). Does Size Matters? Displacement Processes Applied in Urban Development Projects in Dar es Salaam City. Journal of Building and Land Development, 18, 87-107.

National Bureau of Statistics (NBS) and Office of Chief Government Statistician (OCGS), Zanzibar (2013). 2012 Population and Housing Census: Population Distribution by Administrative Units, Key Findings. Dar es Salaam, Tanzania: NBS and OCGS.

Patel, S., Sliuzas R., \& Mathur, V. (2015). The Risk of Impoverishment in Urban Development-Induced Displacement and Resettlement in Ahmedabad. Environment \& Urbanization. International Institute for Environment and Development (IIED), 27, 
231-256. https://doi.org/10.1177/0956247815569128

Robinson, W. C. (2003). Risks and Rights: The Causes, Consequences and Challenges of Development-Induced Displacement. The Brookings Institute-SAIS Project on Internal Displacement. An Occasional Paper. Washington DC: The Brookings Institute.

Stanley, J. (2004). Development-Induced Displacement and Resettlement. Expert Guide. Oxford: Forced Migration Online.

http://www.forcedmigration.org/research-resources/expert-guides/development-induc ed-displacement-and-resettlement/fmo022.pdf

Tanzania Airports Authority (TAA) (2010). Bulletin.

The World Bank (2001). Operational Policies OP4.12, Involuntary Resettlement (New York: World Bank Operational Manual). Washington DC: World Bank.

United Republic of Tanzania (URT) (1997). National Land Policy (2nd ed.). Dar es Salaam: URT.

United Republic of Tanzania (URT) (1999). The Land Act of 1999. Dar es Salaam: UTR.

United Republic of Tanzania (URT) (2005). The Constitution of the United Republic of Tanzania of 1977. Dar es Salaam: URT. 